\title{
EDITORIAL
}

\section{DEPRESI PASCA SKIZOFRENIA}

\author{
Christiane Marlene Sooai \\ Fakultas Kedokteran Universitas Kristen Duta Wacana
}

\begin{abstract}
Gangguan jiwa merupakan masalah kesehatan yang menglobal, berdasarkan data WHO pada tahun 2013, terdapat 450 juta orang yang mengalami gangguan jiwa atau setidaknya 1 dari 4 orang di dunia mengalami masalah mental dan masalah kesehatan jiwa. Menurut sumber yang sama, Skizofrenia merupakan salah satu bentuk gangguan jiwa berat yang dialami 21 juta orang diseluruh dunia. Psikosis, termasuk skizofrenia dengan karakteristik gangguan pada pola berpikir, persepsi, emosi, bahasa, serta kesadaran diri dan tingkah laku. Gejala psikotik yang biasa ditemukan adalah halusinasi pendengaran, penglihatan, dan delusi.

Sekitar $25 \%$ dari total pasien skizofrenia mengalami keterkaitan dengan depresi, dan berdasarkan klasifikasi diagnostik yang termuat dalam PPDGJ III (Pedoman Penggolongan dan Diagnosis Gangguan Jiwa III) seorang dengan kondisi depresi pasca skisofrenia akan menunjukkan gejala depresi yang lebih menonjol dibandingkan dengan gejala skizofrenianya. Gejala tersebut dapat terjadi pada kurang dari 10 hingga 70 persen pasien pasca skizofrenik.

Depresi pada pasien pasca skizofrenia ini dapat mempengaruhi hubungan sosial mereka, seperti kehilangan orang-orang yang dikasihi dalam hidup dan dapat menjadi pemicu menurunnya keinginan hidup pasien bila tidak ditangani dengan baik. Hal ini menunjukkan pada kita tentang betapa pentingnya mengenali depresi pasca skizofrenia dan penanganannya.

Pada Terbitan edisi ini, BIKDW mengangkat topik yang sangat menarik mengenai penelitian yang berkaitan dengan Efektifitas permainan Kearifan Budaya Lokal dibandingkan Neurofeedback terhadap derajat depresi pada pasien pasca skizofrenia. Semoga artikel ini dapat memperkaya wawasan dan pengetahuan kita mengenai salah satu aspek penanganan pasien depresi pasca skizofrenia.
\end{abstract}

\section{DAFTAR PUSTAKA}

1. World Heath Organization (WHO),mental disorders, Fact sheet. April 2016.

2. Current psychiatry, evidence based reviews, treating depression in patient with schizophrenia. Cited 29 June 2016. 